\title{
COMPARATIVE ADMINISTRATIVE LAW: A NOTE ON REVIEW OF DISCRETION
}

\section{Fritz Morstein Marx $\dagger$}

During the past century, industrialization proceeded primarily on the formula of free opportunity and individual management. A fully developed industrial order, on the other hand, can find the rationale of its existence and managerial orientation only in its relationship to the national community at large. Authoritative definition of this relationship is essential to both the security of investment and the stability of the social system. The definition is supplied in government regulation. The scope of government regulation is bound to increase as the emergent industrial society approximates integration. Effective government regulation cannot rely on statutory guidance alone. Resort to administrative power is required in order to transform the general norm into behavior patterns. Public administration is a "fitting" process, combining subservience to authorization with creative adjustment.

These are, in a nutshell, the dominant factors conditioning the modern "service state". ${ }^{1}$ More than ten years ago, Ernst Freund observed here and abroad "a growing tendency to have recourse to administrative powers . . ."-independent of any "bureaucratic tradition". ${ }^{2}$ The far-reaching reform measures adopted under the auspices of the New Deal have placed the trend in sharp relief. As a "fitting" process, public administration cannot fulfill its function without the use of discretion. In consequence, adequate control of administrative discretion is today a matter of vital concern to the citizen affected by administrative acts. ${ }^{3}$ Equally vital is the community interest in preventing discretion from transgressing its legal mandate.

$\dagger$ J.D., I922, University of Hamburg, Germany; Assistant Professor of Government, Harvard University.

I. White, Trends in Public Administration (1933) $34 x$.

2. Freund, Administrative Powers over Persons and Property (ig28) 580. This tendency, as an inherent necessity of the "service state" must be distinguished from the ascendancy of executive leadership within the framework of constitutional government. The latter development testifies to the increasing prominence of the planning function (policy formulation) and the difficulties attending the discharge of this function by parliamentary bodies. Cf. GIRAUD, LA CRISE DE LA DEMOCRATIE ET LE RENFORCEMIENT DU POUVOIR EXÉCUTIF (I938); Loewenstein, The Balance between Legislative and Executive Power: A Study in Comparative Constitutional Laze (I938) 5 U. OF CHI. L. REv. 566. This does not mean that both trends are entirely unrelated to one another. Cf. Morstein Marx, Verwaltungsreform in den Vereinigten Staaten (I933) 38 VERWALTUNGSARCHIV 63 et seq. One of the best illustrations is the REPORT OF THE President's Committee on Administrative Management (I937). A British parallel is the Report (CMd. 4060) of the Commitree on Ministers' Powers (i932).

3. The problem extends far beyond the sphere of the so-called independent regulatory commissions. To concentrate on a solution for this specific province-as does Landis, The Administrative Process (I938) - may jeopardize the desirable unity of 
Continental European administrative law has attempted to accomplish both these ends. Under the circumstances, comparative analysis should prove fruitful. As the pressure toward a fuller utilization of administrative power appears to be inherent in the growth of industrial organization, techniques of accommodation elaborated abroad at an earlier date have acquired a new relevance in our own quest for a solution. Systematic treatment of French and German administrative law has received a strong impetus. ${ }^{4}$ The merit of such systematic examination cannot be in doubt. The approach, however, needs implementation in terms of comparative case analysis focusing on specific legal situations. It is the purpose of this article to suggest the potentialities of "situational" case analysis." The following pages

administrative law, an objective that should gain fuller recognition in present-day discussions. The chief significance of administrative law must be found in its carry-over effect upon the conduct of public administration as a whole. Its permeation of the "administrative mind" is more important than the fact that it supplies the legal norm which governs the decision of a concrete dispute. Moreover, the new prominence of the planning function (see supra note 2) makes the status of the independent regulatory commissions distinctly problematical. Cf. Cushman, The Problem of the Independent Regulatory Commissions, President's Conmintee on Administratrve Managearent, Report with Spectal Studies (1937) ; Brookings Institution, Report on the GovmRnaient Activities in the Regulation of Private Business Enterprises, No. IO, Report to (Senate) Select Committee to Investigate the Executive Agencies of THE GovernMENT, 75th Cong., Ist Sess. (1937); Rogers, The Independent Regulatory Commissions (I937) 52 Pox. Scr. Q. r.

4. Among the most recent literature, mention may be made of Jacoby, Delegation of Powers and Judicial Review: A Study in Comparative Law, 4 SELECTED Essays on Constitutionax LAw 3I6; Riesenfeld, The French System of Administrative Justice: $A$ Model for American Law? (I938) I8 B. U. L. REv. 48, 400, 715; Uhler, The Doctrine of Administrative Trespass in French Law: An Analogue of Due Process (1938) 37 MiCH. L. Rev. 209; Uhlman and Rupp, The German System of Admintistrative Ccurts: A Contribution to the Discussion of the Proposed Federal Administrative Court. (I937) 3I ILL. L. REv. 847, r028.

Unfortunately, little material is available in English on Italian administrative law, although the contribution of Italian jurisprudence to this field is important. Its comparative significance is perhaps sufficiently suggested by the fact that National Socialist writers have come to denounce its "liberalistic extremism". Cf. IPSEN, PoLITIK UND Justrz (I937) 202, n. 67. A classic in the field is I \& II ZaNOBINI, CoRso DI DIRITTO Aarministratrvo (1936-1938). Other standard works are: BoRsi, IAA Grustizia AMIarINISTRATIVA (6th ed. 1938); I \& II FERRARIS, DiRITTO AMMITNISTRATIVo (I922-I923);

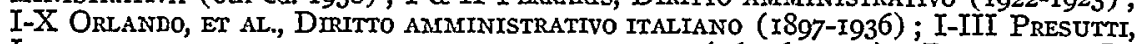
IstituzionI DI DIRITTO aMIMINISTRativo ITALIANo (3d ed. I934); RANELLETTI, LE Guarentigie della Guistizia nella Pubblica Amiministrazione (4th ed. I934); La Torre, Elementi dr Diritro Amrinistrativo (I925). Continental European doctrine has spread not only to the Balkans but also to Latin America. Concerning the latter cf. Brelsa, Derecho Administrativo y Legislactón Administratrva ArgenTINA ( $3 \mathrm{~d}$ ed. I938). Concerning the former, it may suffice to refer to KrBEK, DiskRECIONA OCJENA (1937), a comprehensive discussion of judicial review of administrative discretion by a Yugoslav scholar.

5. Continental European administrative law lends itself to "situational" case analysis because, in contrast with the tradition of codification in other areas of law, it corresponds closely to the common law pattern. Its chief characteristic is its judicial basis -it is judge-made law. Its systematization does not rest on statutory formulation but on the contribution of legal scholarship set forth in comprehensive treatises of individual authors, mostly teachers of administrative law. Administrative justice recognizes these treatises as authoritative. The intimate connection between theory and practice has also found expression in the organization of the administrative courts. In Germany, 
are intended as a tentative outline for use by others and as a topical comment as well.

In the United States, "administrative law is groping". 6 It seems to imply a challenge to our "judicial tradition"." Its place within the ideology of checks and balances is considered problematical-an ideology proclaimed "inseparable from a well ordered society in the English-speaking world". : At the same time, a "well ordered society" cannot afford to be indifferent to any legal uncertainty attending the exercise of administrative power. It is futile to eulogize the "rule of law" if it fails to offer practical safeguards of legality in the expanding realm of relationships between administrative authority and the individual. In the texture of these relationships, the manifestations of quasi-judicial and quasi-legislative power as vested in the so-called independent regulatory commissions represent no more than a number of major threads. The case to which we $\operatorname{turn}^{9}$ here is outside these specific categories. It is a plain licensing case.

The Massachusetts statute governing the granting of licenses to restaurant businesses directs "common victuallers" to be provided at

for instance, professors of public law have frequently served at the same time as members of the higher administrative courts. Thus a fruitful exchange between academic teaching and judicial experience was achieved, comparable to the far-reaching influence exerted by the sapientes in the resurrection and revitalization of Roman law in medieval Italy. Cf. EngelmanN, DIE Wiedergeburt der ReCHTSKultur In Italien (I938); Kantorowicz, Studies in the Glossators of the Roman LaW (1938).

"Situational" case analysis provides opportunities for ascertaining the factual conditions confronting the administrator in making his decision. Here we discern a significant zone of contact between administrative law and public administration. Familiarity with the fundamental problems of administrative law is today indispensable for the administrative officer in responsible position. The approach to public administration would probably become more fruitful by a closer orientation to administrative law. This idea seems to be taking hold among teachers of public administration. Cf. FIELD, Research in Administrative Law (I938) ; Social Science Research Council, Committee on Public Administration, Legal Aspects of Public Administration (1939). In the university training for the higher administrative career, continental European countries place emphasis on administrative law. Cf. Morstein Marx, Civir Service in Germany, Civil Service Abroad (I935) 21o, 223 et seq.; Sharp, The Government OF THE FRENCH REPUBLIC (1938) i56 et seq. In the elaboration of administrative law account must be taken of the need for supplying the administrator with a guide to constructive solutions. "Situational" case analysis will tend to accentuate this necessity.

6. Frankfurter and Davison, Cases and Materials on Administrative Law (2d ed. I935) vi.

7. American Bar Assoctation, Advance Program, Report of the Spectal ConMITTEE ON ADMINISTRATTVE LAW (1938) I5\%.

8. Id. at 145 .

9. Liggett Drug Co., Inc. v. Board of License Com'rs of City of North Adams, 4 N. E. (2d) 628 (Mass. 1936) ; J. J. Newberry Co. v. Same, ibid. See (I937) 3I ILL. L. REv. 1089. The Liggett and Newberry companies each filed a petition for mandamus, and a bill in equity to enjoin interference with the business. The four cases were consolidated. Decision on the bills in equity hinged on the outcome of the mandamus proceedings, and no further mention of them will be necessary. The underlying facts of both mandamus petitions were substantially identical. The presentation of the case in the text is based on the papers on appeal and the briefs. 
all times with "suitable food for strangers and travelers", ${ }^{10}$ and to have upon their premises "the necessary implements and facilities for cooking, preparing and serving food for strangers and travelers". ${ }^{11}$ These are the only express qualifications, apart from the obligation to refrain from conducting the business "in an improper manner". ${ }^{12}$ The statute states also that the law "shall not require the licensing authorities" to grant a license "if, in their opinion, the public good does not require it". ${ }^{13}$ Petitioner, a chain-store corporation operating a large number of stores in Massachusetts, had for several years been licensed as a "common victualler" by the Board of License Commissioners of the City of North Adams. Apart from the sale of merchandise, the store maintained a soda fountain and served meals. Petitioner, against whose business conduct there had never been complaint, filed application for the annual renewal of its license in November, I935. On December I4, the Board informed petitioner that it had "declined to renew" the license.

Two days later, the North Adams Transcript carried an article on the Board's action. The article, based on an interview with the chairman of the Board, stated that the Board, according to its chairman, had acted to "protect big-tax-paying restaurants from the competition of establishments that are serving meals only as a side line and that pay almost nothing in taxes toward the support of the municipal government". The article further quoted the chairman as saying that the enterprise, being a corporation, pays no local taxes on real estate holdings or its stock and contributes to the support of the city government only the small portion of its relatively light corporation taxes which the Commonwealth returns to the municipality. "Restaurants operating solely as such, on the other hand, pay heavy taxes locally and in many cases pay the city also the substantial fees and charges for liquor licenses." The locally owned restaurants, "in the light of these facts", required protection from such competition. Such was the chairman's announcement. Petition for mandamus, after hearing, was dismissed by the single justice "on the merits". ${ }^{14}$ The justice made no findings of facts.

The Supreme Judicial Court, confronted with petitioner's bill of exceptions, took for its point of departure the character of the remedy requested. Petitioner, "in order to prevail, must show that as a matter

IO. MASS. GEN. LAwS (1932) c. I40, $\$ 5$.

II. Id. at $\$ 6$.

I2. Id. at $\$ 9$.

I3. $I d$. at $\$ 2$.

I4. The single justice is a member of the Supreme Judicial Court assigned to circuit duty. Petitioner requested of the single justice fourteen rulings of law, two of which were granted, while the remaining were denied as requested, but most were granted as modified by the judge. 
of law it is entitled to such license, or that in refusing to grant the license the respondents have proceeded upon grounds erroneous in law or have otherwise violated legal rights of the petitioner". ${ }^{15}$ As to the scope of its review, the court held that "the general finding of the single justice in favor of the respondents imports a finding of all the incidental and subsidiary facts necessary to that conclusion permissible on the evidence". ${ }^{16}$ More specifically, "the question presented on this branch of the case is whether the decision of the single justice can be supported as matter of law upon any rational view of the evidence. That decision is not reviewed or revised, but is conclusive if supported by evidence". ${ }^{17}$

Turning to the evidence, the court took cognizance of the following records of the respondents. The crucial vote had been passed "after taking into consideration all of the angles under Chapter I40", ${ }_{18}$ and in response to the motion that the application in question "be denied on the ground that the public good did not require it and that serving meals in the same room where the sale of merchandise is actively carried on is detrimental to the public health". Under the same date there was another entry: "The Board feels also that on account of so many common victualler's licenses, consideration should be given to those who do a regular restaurant business and nothing else, and have expensive equipment and pay the city extra money in taxes and license fees, and so forth." Finally, there was a notation on the record book of the respondents carrying the same date as the vote: "Place of service, poor. So-called kitchen in cellar where food was prepared and sent upstairs by dumb lift. Day light very poor." On this point, one of the respondents had also given testimony ${ }^{19}$

I5. The court referred to Crocker v. Justices of the Superior Court, 208 Mass. I62, 164, I65, 94 N. E. 369, 37I (I9II) ; Knights v. Treasurer \& Receiver General, 236 Mass. 336, 337, 128 N. E. 637 (1920) ; Milton v. Auditor of the Commonwealth, 244 Mass. 93, 96, I38 N. E. 589, 590 (I923) ; Madden v. Board of Election Commissioners, 25 I Mass. 95, IOI, I46 N. E. 280 , 282 (I925).

I6. Italics supplied. The Court referred to Blake v. Hammersley, 288 Mass. 247, 249, I92 N. E. 506, 507 (I934).

I7. Italics supplied. The court referred to Andrews v. Registrars of Voters of Easton, 246 Mass. 572, 576, I4I N. E. 507, 508 (I923); Moss v. Old Colony Trust Co., 246 Mass. I39, I43, I 40 N. E. 803, 804 (I923) ; Swift v. Registrars of Voters of Quincy, $28 \mathrm{I}$ Mass. 27I, 284, I83 N. E. 730, 735 (1932). These three decisions contain, with minor modification, formulations identical with that quoted above.

I8. MASS. GEN. LAWS (1932) c. I40.

19. He testified in part as follows: "Prior to denying the license the board had some information concerning the physical aspects of the . . . premises. This information was confirmed by an inspection made after the proceeding was commenced. With regard to the .. . store, the portion of the cellar in which food was prepared was not partitioned off from the storage places and the rest of the cellar, and a sink and an open trap near the sink down which waste water came was in the cellar, which waste water emptied into the trap and was carried off through the sewer. . . . The inspection confirmed the opinion of the board with regard to sanitary conditions which were considered unfavorable for the preparation of food. There is no daylight in the cellar and the ventilation was very poor. The character of the food was limited, there was no stock of fresh meats and the storeroom contained mostly canned material. There 
aimed at establishing the fact that the Board, in making its decision, had taken into consideration the "physical aspects" of the premises. Other evidence, however, tended to show that petitioner's place of business was "in every way fit for the conduct of a restaurant". On this latter evidence, the court did not express itself; in its own words, "that evidence need not be narrated because the single justice was not bound to give it credence". ${ }^{20}$

Disposing of petitioner's attack on the constitutionality of the statute, ${ }^{21}$ the court concerned itself with the relationship of the evidence to the decision of the single justice. "His general finding in favor of the respondents may have rested" ${ }^{22}$ on the ground that petitioner's place of business was "unsanitary and not suitable for the preparation and sale of food". He "may also have found that it was detrimental to the public health to serve food for immediate consumption in the room where the sale of merchandise was in progress". ${ }^{23}$ $\mathrm{He}$ "may further have found that the decision of the respondents was supported by the facts that too many places had been licensed for public eating houses and that the welfare of the community would be promoted by diminishing that number, and that the methods of business of the petitioner conduced to impair the quality of food dispensed at all such places". ${ }^{24}$ Under the circumstances, "it cannot be held that any of these findings was without support in evidence". As to their

was a toilet at the foot of the stairs about five feet from the sewer pipe which ran directly into the drain pipe from the sink. It confirmed the opinion that we had that the sanitary conditions were not right for the preparation of food and that fact was to be considered as a vital fact in coming to that opinion. In addition, the board felt that to serve food in a drug store with all sorts of drugs and possible poisons and acids and so forth was not proper, where people were coming in and general merchandising was being carried on. The board needed to consider the number of licenses in North Adams because under the conditions of today it felt that the number was seriously handicapping each one of them that was doing business and that it was decreasing their business. The board also felt and took into consideration in reaching its conclusion that [the store] was selling meals at very nominal sums and in this way was forcing competitors to curtail the quality of their goods." Petitioner, on the other hand, averred that the Board had granted a number of licenses to local residents who had entered business after the petitioner. Petitioner also stated that the Board had renewed all licenses other than those for the two chain store corporations.

20. Italics supplied.

2I. In its brief for the Supreme Judicial Court, petitioner devoted most of the space to arguing the unconstitutionality of the statute. This question is discussed in Part III of the brief (pp. 20-72). The question of "abuse of power" is referred to once in passing. It may be remarked that this space allocation reflects the inadequate consideration which the courts accord customarily to the latter issue. Redress is sought primarily in assailing the constitutionality of the statute or ordinance under which the licensing authorities operate. Elimination of the statute or ordinance as an essential byproduct of redress in an individual dispute is a socially uneconomical procedure.

22. Italics supplied. Liggett Drug Co. v. Board of License Comm'rs, 4 N. E. (2d) 628,634 (Mass. 1936).

23. Italics supplied. The court in this connection cited with approval In re Interrogatories of the Governor, 97 Colo. $587,595,52$ P. (2d) 663,667 (1935), quoting from it the statement that "the preparation and service of meals, in the same room where the sale of merchandise is actively carried on, is inimical to the public health".

24. Italics supplied. 
legal significance, "each one of them appears to be a reasonable and nondiscriminatory test. No one appears to be designed to operate against the petitioner on grounds of prejudice, or whim, or caprice. The record does not show that the respondents were actuated by any unworthy motives".

The court reenforced its deduction by reference to two rulings granted by the single justice at the request of the petitioner. The first of these stated: "To refuse to renew a common victualler's license to a petitioner, otherwise qualified, on grounds other than a failure to comply with G. L. c. I 40 (Ter. Ed.) $\$ 6$, or other than because it has done or is doing business in an illegal or unsanitary manner, is improper and illegal." 25 The second ruling said: "To refuse to grant or renew a common victualler's license to a petitioner otherwise qualified, on the ground that the petitioner does not pay local taxes on real estate, is improper and illegal." The court saw in the granting of the first ruling an indication of the single justice's finding that the refusal of the respondents "was based on sound, practical grounds". Concerning the second ruling, the court concluded: "Having thus instructed himself as matter of law the action of the single justice in dismissing the petitions imports a finding that the respondents did not refuse to grant or renew a common victualler's license to the petitioner on the ground stated." As a result, the court overruled petitioner's exceptions.

A critique of the decision, to which we intend to return in the concluding observations of this paper, could perhaps confine itself to the commonplace comment that in the field of actions at law the scope of review on the part of the appellate court is essentially limited. The limitations were outlined by the Supreme Judicial Court in unequivocal terms at the very outset of its decision. Speaking generally, the court defined its function without error; nor do its formulations warrant the charge of excessive narrowness. Yet, the outcome is entirely unsatisfactory for several reasons.

In the first place, the general standards applicable to appellate jurisdiction are ill suited for cases like the present one. Prima facie, the facts of the case pointed in the direction of discriminatory action on the part of the Board. ${ }^{26}$ The single justice, dismissing the peti-

25. Section 6 of the statute refers to the requirements for the common victualler to have ". . upon his premises the necessary implements and facilities for cooking, preparing and serving food for strangers and travelers". MASS. GEN. LAws (I932) c. $140, \S 6$.

26. It is significant that the writer of the Note in (I937) 3 I ILL. L. REv. I089, without apparent knowledge of the evidence pointing to the chain-store question as the chief issue, reports the case under the subtitle: "Licensing as a Method of Destroying the Chain Store". 
tion, "on the merits" without making findings of facts, contributed little to clarify the legal situation. The Supreme Judicial Court in effect restricted itself to supporting hypothetically the conceivable hypotheses of the single justice. In the last analysis, the decision comes close to certifying a carte blanche for the local licensing authorities. ${ }^{27}$

Second, the decision does not demonstrate a full comprehension of the legal problems involved in judicial review of administrative discretion. It goes without saying that administrative discretion operates solely within the framework of its authorization. Each administrative act, to be lawful, must maintain a discernible nexus with the general norm conferring the discretionary power. The existence of such a nexus is in itself a question of law. In this criterion alone lies the distinction between lawful exercise of discretionary power and arbitrariness. The distinction is to a large extent identical with that between proper and improper motivation of the discretionary act. The court progresses into the vicinity of these categories by affirming the absence of "unworthy" motives. But a "worthy" motive is by no means always a proper motive in terms of the nexus criterion. Discretion does not mean freedom to pursue any public purpose. ${ }^{28}$ Reference to the "public good" in the statute directs discretionary contemplation to two areas only: personal disqualification and local need. The former includes the actual conduct of the business; the latter points to the concrete pattern of the community. For the definition of both areas, the practice of the licensing authority is not irrelevant. Refusal to renew the license for an enterprise licensed for several years requires particular scrutiny of the controlling motive.

Third, the three specific considerations attributed to the single justice, each of which was pronounced by the court to be a "reasonable and nondiscriminatory test", are too broad to permit segregation into proper and improper motives. As to the "physical aspects" of the premises, no attempt was made to ascertain whether or not the actual arrangements in petitioner's store had been part of the Board's official knowledge prior to the granting of the last license. The same question arises with respect to the general conclusion that serving food in a room where merchandise is also being sold is "detrimental to the public health". Since the Board had obviously not been controlled by this conclusion in renewing the license in previous years, the change

27. Under the circumstances, "fixing" the licensing authority is the only way out in similar cases-a strange consequence under the "rule of law".

28. In its brief for the Supreme Judicial Court, petitioner barely touched upon this issue. Cf. supra note 2I. The explanation probably lies, at least in part, in the discouragingly narrow precedential basis for the line of reasoning presented in the text. 
of mind should call for a special explanation. ${ }^{29}$ The evidence contains no concrete facts to justify the change of mind. Similarly, concerning petitioner's ability to sell meals "at very nominal sums" ${ }^{30}$ because of its chief reliance on the sale of merchandise, the "combined" character of the business was neither a new discovery nor does it in itself warrant the finding that petitioner "conduced to impair the quality of food dispensed at all [eating] places". Finally, the fact that "too many places had been licensed" does not entitle the Board to pick its victim freely and thus to save itself from the consequences of its own licensing policy. The court fails to indicate a rational standard for the actual choice.

\section{II}

Before progressing further with the analysis, let us now place side by side with this decision a French case. ${ }^{31}$ What should perhaps be emphasized is that the Conseil d'Etat based its decision on the official files (dossier) of the public authority involved-standard practice in French administrative justice. The facts of the case as reported here are summarized from the dossier. ${ }^{32}$ Availability of the official files is of particular importance in ascertaining the motivation of discretionary acts. Little room is left for guesswork if the court of review is placed in a position to follow through the processes leading up to the making of the administrative decision.

In Ig08, the municipality of Cannes authorized, on an experimental basis, the stationing of twelve de luxe automobiles for public use in front of the Municipal Casino. The automobiles received a number each, like horse-drawn cabs, and had to pay an annual stand fee of roo francs; the maximum fare for any trip was fixed at 20 francs. This arrangement continued until the beginning of the winter season of I9I3-I9I4, but it did not meet with public favor. Consequently, the authorization given to the owners of the twelve cars was not renewed, and the numbers were withdrawn. ${ }^{33}$ The decision of

29. Section 9 of the statute contains the following clause: "If a licensee at any time conducts his licensed business in an improper manner, the licensing authorities, after notice to the licensee and reasonable opportunity for a hearing, may upon satisfactory proof thereof suspend or revoke the license." MASS. GEN. LAws (I932) c. 140, $\$ 9$. Although the question of "improper conduct" did not arise in the instant case, the quoted clause offers a lead in the direction suggested in the text.

30. Thus the testimony of one of the respondents. See supra note 19.

3I. Conseil d'Etat, June 8, I9I7 (Ville de Cannes c. Rabé), Sirey I920, III, I.

32. Cf. 2 HaURIOU, LA JURISPRUDENCE ADMINISTRATIVE DE I8g2 À Ig29 (I929) 343 et seq. On the historical development of French administrative justice $c f$. RIESENFELD, op. cit. supra note 4 , at 55 et seq. A useful compilation of the literature on French administrative law and justice is offered therein, $i d$. at $55, \mathrm{n}$. 50 . On the scope of the doctrine of "abuse of power" (détournement de pouvoir), particularly important in the control of administrative discretion, $c f . i d$. at 425-426.

33. No litigation resulted from this measure. It must be kept in mind that the numbers were granted provisionally, subject to the termination of the "experiment". 
the municipality was governed by the thought that, in view of the competition suffered by the street cars, it was inopportune to increase permanently the number of vehicles available for public use.

In its meeting of September 24, I9I3, the municipal council voted to invite the owners of horse-drawn cabs in possession of numbers to change to taxicabs, as contrasted with de luxe automobiles, provided that at least ten would effect this change. Those substituting taxicabs for horse-drawn cabs soon exceeded ten. In October, the mayor, in exercise of his ordinance-making power, ${ }^{34}$ adopted a regulation concerning the operation of these taxicabs. Section I6 of the ordinance placed the taxicabs under the same rules as were in effect for horse-drawn cabs, providing also that the former could use the stands available for the latter.

The net result of these measures ${ }^{35}$ was that those owning horsedrawn cabs at the time of the council's vote obtained a monopoly. On the one hand, the number of cabs was not to be increased; on the other hand, only the existing cabs in possession of a number could change to automobile operation. Besides, the cab owners were organized in a trade association. Thus the Cab Owners Association became what amounted to a closed corporation, vested exclusively with the right to use the public stands not only for horse-drawn cabs but also automobile taxis.

In January, I9I4, plaintiff applied to the mayor for authorization to operate for public use one of the original de luxe cars which he claimed to have acquired. His request was based ${ }^{\mathbf{3 6}}$ on the fact that the car had been one of the ten operating under a number up to I9I3. The Cab Owners Association protested. The mayor refused the application on the ground that the municipality did not intend to increase the number of vehicles available for public use. He added, however, that if plaintiff became the owner of one of the existing cabs, the municipality would be willing to transfer the number of the cab to him. Plaintiff brought suit against the municipality.

The Conseil d'Etat annulled the decision of the mayor. It pointed out that under the laws the authority of the municipality was confined in this matter to the maintenance of public order and the regulation of traffic (le bon ordre et la circulation). It declared the restrictions put into effect by the mayor in consequence of the council vote "in-

34. For the statutory basis of this ordinance-making power, see the reasons given in the decision of the Conseil d'Etat, below. The powers of mayors are enumerated in the Loi sur l'organization mminicipale of April 5, I884 (28 BULLETIN DES LoIS 369) $\$ 73$ et seq.

35. Cf. 2 HAURIOU, op. cit. supra note 32 , at 345 .

36. Legally, the reason advanced was not conclusive. See supra note 33. The Conseil d'tat did not concern itself with this reason in its decision. In his comment, Hauriou pays no attention to it. 2 HAURIoU, op. cit. supra note 32 , at 345 . 
spired by interests other than those of public order and traffic control". It pronounced plaintiff "entitled to maintain that, in applying these measures to him and in refusing to issue a number for the car owned by him", the mayor had used his powers "for a purpose other than that with regard to which they were granted him". In this "discreet" ${ }^{37}$ formulation, the decision indicates the distinction between proper and improper motivation, without concerning itself directly with the issue raised by the monopolistic structure of the Cab Owiners Association. Indirectly, however, the decision effectively disposes of the monopoly.

In its tenor, the decision is in harmony with precedent. In the Bouchardon case ${ }^{38}$ the Conseil d'Etat had laid down the rule that municipal authorities cannot lawfully regulate vehicles for public use in such a way as to establish virtually a monopoly for one particular entrepreneur. The present decision, however, extends further. Instead of protecting the interests of a particular entrepreneur, the mayor's action in effect sustained the collective interests of the Cab Owners Association. The decision makes plain that the same considerations governing the factual monopoly of a single entrepreneur apply to the monopole de fait of an association of entrepreneurs pursuing its occupational group interests. ${ }^{39}$ In other words, it is a discriminatory test to condition the admission of a vehicle for public use upon the applicant's membership in a trade association. Under such a practice, the trade association would obtain semi-public character (création indirecte de corporation municipale). In the present case, access to membership was open only to the purchaser of one of the existing cabs. By suggesting this avenue to plaintiff, the mayor made himself the representative of the interests of the Cab Owners Association. His action was incompatible with his status as an administrative officer exercising regulatory powers defined by both the statutes governing municipal authorities and the general principle of freedom of competition, recognized in French law.

The decision of the Conseil d'Etat reflects an inclination, manifest throughout the realm of French administrative justice to protect intentionally or unintentionally the competitive interests of the small-scale entrepreneur. ${ }^{40}$ The decision also mirrors the widespread fear of

37. Id. at 346 .

38. Conseil d'Etat, Aug. 2, I870, Sirey I872, II, 288.

39. 2 Hauriou, op. cit. supra note 32 , at 346 .

40. A good illustration of this tendency is the recently advanced (but not yet seriously pursued) project for what amounts to a "small NRA" for minor and middle-sized enterprises. The plan is most sensitive to the independence of individual enterprise. It is outlined in Coutrot, Proposals for a Laze on Industrial and Commercial Organization, Proceedings of tae Seventh International Management Congress, General Management Papers (1938) 29 et seq. Cf. Morstein Marx, National and Economic Significance of Scientific Management (Rapporteur's Critique) id. at ra et seq. 
syndicalisme, whether in the form of employee organizations or that of trade associations. Hauriou, in his comment on the decision, ${ }^{41}$ emphasizes the statutory basis of the "freedom of commerce and industry", one of the accomplishments of the French Revolution. If there be syndicalisme, he argues, it must find its foundation in new legislation. In the absence of such legislation, it cannot be the task of the police authorities to proceed without express authorization. To him, the decision suggests the following rules. First, qualified by "reasons of public order of absolute necessity", the municipal police power does not extend to "organizing in corporations" 42 the industries which touch upon the traffic on public roads". Second, the municipal police power may not attempt to reach the same result "by resorting to some detour device". Any approach toward setting up a public utility of this character should be in the form of a direct and straightforward "règlement de principe", subject to attack before the administrative courts. Such a règlement de principe had been approved by the Conseil d'Etat in the Boudhir case. ${ }^{43}$ In that case the mayor had established on the municipal market square a corps of porters placed under the orders of a manager, reserving for himself the supervision of the enterprise.

Hauriou's conclusion deserves citation in full: "The municipality of Cannes had observed neither the one nor the other of the two conditions. On the one hand, no absolute necessity of public order could have required the limitation of the number of vehicles for public use and the organization of those existing in an enterprise vested with a quasi-official status. On the other hand, the combination of the owners in a corporation municipale ${ }^{44}$ had been the result of indirect measures. The combination sprang from the fact that the owners themselves were organized and that the municipality responded to their suggestions in refusing the admission of new vehicles. This was a corporation de fait, a shameful creation, ${ }^{45}$ to which the Conseil d'État could not concede juridical existence." 40 One may add that French administrative justice is not sympathetic toward the clandestine formation by municipalities of economic satellites which are not placed in a clear legal relationship to the statutory basis of municipal authority.

The Conseil d'Etat, reconstructing the concrete situation from the official files of the municipality, did not confine itself to an inquiry

4I. I2 HAURIOU, op. cit. supra note 32 , at 347 .

42. In the sense of French legal terminology.

43. Conseil d'Etat, Dec. 9, I904, Sirey I906, III, I54.

44. In the sense of French legal terminology, meaning a corporate body organized by a municipality.

45. Hauriou's words are "une corporation honteuse".

46. I2 HAURIOU, op. cit. supra note 32 , at $347-348$. 
into the good faith of the mayor. It did not restrict the area of its review to the question whether or not "practical grounds" or "worthy motives" had governed the mayor's action. It would be extravagant to call the mayor's action "impractical" or guided by "unworthy" motives. The decisive criterion was that of the nexus between the refusal of plaintiff's request and the statutory foundation of the mayor's authority. His restrictive measures, in the words of the Conseil d'Etat, were not "inspired" by considerations of public order and traffic regulation. They had resulted from considerations of official convenience: to work out a local arrangement of apparent practicality. The arrangement, however, transcended the mayor's authority because of its discriminatory effect. Police measures may qualify the "freedom of commerce and industry", but their character. and scope must be justified by a direct "police interest". The specific nature of the regulation effected by the mayor of Cannes could not be retraced to such a direct "police interest". As a consequence, although in good faith and motivated by administratively "sound" reasons, he had acted outside the bounds of the law.

The case demonstrates two things. In the first place, French administrative justice does not attempt to review discretion by focusing on the question whether or not the statute sets forth sufficiently concrete criteria to guide administrative action. ${ }^{47}$ Under modern conditions, emphasis on such express criteria is bound to operate on the unrealistic imputation of legislative omniscience. In contrast with this emphasis, French decisions derive implicit criteria of proper administrative motivation from the controlling statutory clause, and hence review discretion in terms of its individual manifestations. Second, in doing so the Conseil d'Etat, scrutinizing the official records, treats the existence of the nexus between authorization and execution as a question of law. Instead of entertaining more or less artificial hypotheses, it instructs itself fully as to the relevant facts, thus placing itself in a position to clarify the legal situation in its entirety. As a result, French administrative law, in the happy phrase of Berthélemy, has become "a real equity". 48

\section{III}

While in France the unity of administrative law is preserved by the central position of the Conseil d'Etat, Republican Germany, like the pre-war Kaiserreich, lacked a National Supreme Administrative

47. With respect to ordinance-making powers, the American doctrine is stated in very broad terms in Panama Refining Co. v. Ryan, 293 U. S. 388 (I935). Cf. Jacoby, loc. cit. supra note 4 , for a comparative analysis.

48. Berthélemy, The Conseil d'Etat in France (I930) I2 J. Conp. Leg. AND INTERNAT. LAW 23, 32. 
Court. The Weimar Constitution, however, envisaged an organizationally integrated system of administrative adjudication, ${ }^{49}$ although it retained the federal structure of government. Each state maintained its own machinery of administrative justice. As to the concepts and principles of the substantive law, on the other hand, the administrative courts, national and state, treated the precedents of different jurisdictions and the writings of the authorities as part and parcel of one common body of legal rules. On certain points, doctrinal differences could arise. But these were the exception, and did not seriously affect the general pattern.

Under the laws of the state of Hamburg, the acquisition by corporations of real estate exceeding in value a defined minimum was conditioned on the consent of the Department of Justice. The statute further provided that the consent was subject to a fee of one per cent of the assessed value of the property. In introducing the bill in the state assembly, the cabinet had given two reasons for the proposed legislation. The first was that the growing housing shortage made it imperative to take "all steps" that seemed appropriate to meet the situation. The second was that measures were required to combat the ill effects of increasing control of real estate by foreigners who utilized the device of German straw corporations in order to circumvent the legal barriers blocking their direct acquisition of properties. ${ }^{50}$

Plaintiff, a large Hamburg shipping enterprise, having bought a property exceeding in value the legal minimum, applied for consent. The Department of Justice intimated that there were no particular objections to the transaction, but that consent, in harmony with its established practice, would be given only if plaintiff, apart from the fee, would contribute a specified sum to the Housing Fund adminis-. tered by the Housing Commissioner. Plaintiff replied that it did not consider itself obligated to comply with this demand, but that it would be willing to pay without prejudice to its right to appeal to the courts. After payment, consent was given. By its subsequent suit, plaintiff

49. Article 107 of the Weimar Constitution provided that "in the Reich and in the states there must exist, in accordance with the laws, administrative courts for the protection of individuals against orders and decrees of administrative authorities". On these courts, national and state, see Uhlman and Rupp, loc. cit. supra note 4 . In the Third Reich, the jurisdiction of the administrative courts has been limited by the exemption of the so-called "political" measures from judicial review. Otherwise, the system of administrative justice has been retained without substantial impairments. $C f$. id. at I045-I046; Morstein MARx, Governarent IN THE Third Reice (2d ed. I937) I 44 et seq. Ipsen, op. cit. supra note 4 , at 275 et seq., proposes to solve all political conflicts by recognizing the right of the government to preclude from administrative litigation any individual measures declared by the government to be fraught with political connotations.

50. In this respect, the act (passed in I920) attempted to check the tendency of foreign interests to utilize the post-war currency inflation in Germany for securing economic values at a price often hardly more than nominal. 
attempted to recover the sum contributed to the Housing Fund. The suit was successful. ${ }^{51}$

The administrative court, being the court of first resort, ${ }^{52}$ concluded from the silence of the statute that it had left the determination of the conditions under which the consent was to be given to the discretion of the Department of Justice. "Hence defendant, generally speaking, is entitled to attach to the consent certain conditions or specific stipulations. It goes, however, without saying that defendant must observe defined limits, and that it may not abuse its power in this respect." Citing with approval one authority, ${ }^{53}$ the court summarized the principles governing the exercise of administrative discretion to the effect that "it would be an illicit transgression of the bounds of discretion, hence abuse of discretion, hence unlawful action, if the exercise of discretion were determined by extraneous considerations, and further, that in each single case the department in exercising its discretion may take cognizance of only those factors which the statute intends to be considered in a case of this kind".

In accordance with the principles enunciated, the court turned to the question ${ }^{54}$ of whether or not "the demand of a special levy, besides the fee provided in the statute, is encompassed by the purpose of the statute". Reviewing the legislative history of the statute, the court satisfied itself that in the enforcement of housing and rent legislation frequent difficulties had arisen from the complexities of corporate management in cases where the responsible landlord was a corporation; the statute was designed to eliminate such difficulties in the future by giving an opportunity to check the acquisition of real estate by corporations. The second dominant consideration had been the thought of protecting real estate against the inroads of foreigners. In the light of its findings, the court declared the dual purpose of the statute "clearly discernible". It proclaimed defendant "forced to keep within the bounds thus drawn in the administration of the statute".

5I. Hamburg Administrative Court, Aug. I8, I924 (I925) 8 Hanseatische RechtsZeitschrift I30; Hamburg Supreme Administrative Court, Nov. 5, I924, 8 Hanseatische Rechts-Zeitschrift I32.

52. The text of the Hamburg Administrative Judicature Act is reprinted in somewhat abridged form in Morstein Marx, Die Verfassungs- und Verwaltungsrechtsentwicklung in den drei Hansestädten Hamburg, Bremen und Lïbeck, I918-1928 (I928) I6 JAHRBUCH DES OFFFENTLICHEN RECHTS 5I, 75 et seq.

53. Perels, Darf die Verwaltungsbehörde die Erteilung einer in ihr freies Ermessen gelegten Genehmigung von der Zahhnng einer gesetzlich nicht vorgesehenen "Gebiihr" abhängig machen? (I924) 6 ARCHIV DES OEFFENTLICHEN RECHTS (NEw SERIES) 93, 97.

54. The court correctly considered this question a question of public law. In elaborating this point in its decision, it cited with approval Morstein Marx, Zur Lehre vom Erstattungsanspruch bei Ungiiltigkeit der schnldbegriundenden Rechtsnorm (I924) 7 HANSEATISCHE RECHTS-ZEITSCERTFT 527, 534-535. 
By transcending the limits indicated, defendant had "committed an abuse of discretion and hence an illegal act". 55

No legal significance was attributed by the court to the fact that the printed justification of the bill, as distributed for the use of the legislative assembly, had referred to the necessity of taking "all steps" appropriate to mitigate the housing shortage. Defendant had argued that this language offered a basis for its demand since the demand, made always in agreement with the Housing Commissioner, aimed at mitigating the housing shortage. The court declared defendant's interpretation erroneous. It pointed out that the language was merely of an introductory character, containing no specific information as to the concrete purposes pursued by the bill. The court substantiated its own view also by reference to the statute itself. The provision relating to the imposition of fees was cited as evidence that the statute concerned itself with the scope of plaintiff's financial obligations. In the absence of any other indication, the court saw in the provision an "exhaustive regulation".

On the defendant's appeal, the State Supreme Administrative Court ${ }^{56}$ affirmed the decision. In the main, it confined itself to supplementing the reasons of the court of first resort. It entertained no doubt as to the lack of a legal foundation for any levies in connection with the administrative transaction in question, in addition to the statutory fee. It prefaced the body of its decision ${ }^{57}$ by commenting on the content of the official document issued by defendant. Technically, the consent had not contained any condition. It had been given in unqualified form. "Prior to issuing it, the Department of Justice has demanded payment of an amount of money. Plaintiff has paid the amount, and the Department of Justice has received it, under the condition that the courts should determine the validity of the demand. The demand was without any justification. The Department of Justice itself has not been able to offer any ground on which it could base the validity of the demand." 58

Nor would the legal situation be different if defendant had explicitly conditioned the consent upon the payment of an amount of

55. The conclusion is supported by recognized doctrine. "Abuse of discretion is legally equal to excess of discretion." FLEINER, INSTITUTIONEN DES DEUTSCHEN VERWALTUNGSRECETS (8th ed. I928) I46.

56. It may be mentioned that the Hamburg Supreme Administrative Court served also, on the basis of a compact between the three states of Hamburg, Bremen and Lubeck, as the appellate tribunal for administrative law cases arising in the other two states.

57. In passing, the Supreme Administrative Court disposed of the idea that the "established practice" of the Department of Justice could be invoked as the legal basis for the demand addressed to plaintiff.

58. Cf. I Mayer, Deutsches Verwaltungsrecht (3d ed. I924) 250, n. I8. 
money.59 "The statute confers on the Department of Justice the discretionary power to grant or to deny corporations the consent to acquire real estate. It does not determine, nor even suggest, the criteria which should guide the Department in the exercise of this discretion. Under the circumstances, it is not permissible in defining those considerations relevant to the Department's decision on applications for consent to attach any significance to the legislative justification for the bill-quite apart from the general rule that the motivation of the lawmaking body may be utilized for the construction of statutes only with caution. The point of departure must be that administrative agencies are always under the obligation to bring the public interest to bear upon their action; that hence an administrative agency authorized by statute to grant or refuse a consent, without express criteria for its decision, has to derive its standards from the public interest-the public interest in its full meaning, but at the same time the public interest exclusively; that hence, and with regard to the present case, the Department of Justice must refuse the consent if the real estate acquisition is contrary to the public interest-the general interest in the promotion of housing or the preservation of German control of real estate, or another general interest; that on the other hand the consent must be given if the real estate acquisition is not contrary to the public interest, or even serves the public interest." 60

The effect of this deduction is both far-reaching and obvious. Administrative discretion, instead of giving leeway for choice, is being resolved into a set of official obligations. ${ }^{61}$ "In the present case, the public interest, if not served by the real estate acquisition, has certainly not been disadvantaged or endangered by it-a fact not contested by the Department of Justice. Consequently, the consent had to be given, and its refusal would have been an obvious abuse of the discretionary power conferred upon the Department by the statute. In particular, the Department was not authorized to capitalize on the extensive power placed in its hands, even if it were for an entirely laudable purpose, by making the granting of the consent dependent upon the payment of an amount of money. The statute and its purposes do not suggest the slightest indication of a legal basis for such a demand. It may be added that there would have been no reason whatever for authorizing this kind of action. In the first place, one simply cannot conceive of

59. For a similar case, see Bavarian Oberstes Landesgericht, Mar. 26, 1912, 33 Reger's Entscheidungen der Gerichte und Verwaltungsbehörden 27.

60. "Truly free discretion, i. e., discretion dependent solely on volition, does not exist in the sphere of public administration, but only discretion according to official duties." SCHELCHER, JUSTIZ UND VERWALTUNG (I9I9) 42.

6r. "The authorization to exercise free discretion does not embrace the freedom to act arbitrarily." Prussian Supreme Administrative Court, Apr. 27, I88r, 7 Entscheidungen des Preussischen Oberverwaltungsgerichts 306. 
any ground for burdening corporations acquiring real estate with a tithe considered justified by the Department, in addition to the general levies and costs attending real estate acquisitions, which are at present extremely high. Second, it would be impossible to assume that a well ordered polity should attempt to balance its budget with revenues the amount of which is determined by the changing ideas entertained by an administrative agency, affected in turn by the changes in the responsible personnel." 62

In view of the facts of the case, the State Supreme Administrative Court saw no reason to address itself to the question whether or not the legal situation would be different if plaintiff had yielded to the demand of the Department of Justice and paid the demanded sum of money without reserving its rights. The guiding principles to be applied to such circumstances, however, are not ambiguous. They may be summed up as follows: "In the sphere of administrative law, the fundamental rule is recognized that administrative agencies may not attempt to realize ends denied them under the principles of public law by resort to the detour device of private agreement with the citizen. It is correct to say that no administrative agency may bargain with the citizen for such special rights within its functional province, in terms of a civil law contract, as do not flow from the general public law relationship between administrative authority and the individual subject to it, and hence are encompassed by this relationship." ${ }^{3}$

The practical importance of these principles is self-evident. "It accords with the wisely considered intention that administrative law, in regulating the relationship between administrative authority and the individual, tries to preserve the very idea of law by establishing strict delimitations. In the field of German police law, the administrative courts, faced with a general clause authorizing police action, have prudently developed the counterpart of a detailed system of legal barriers to this authority. The doctrine qualifying the exercise of discretion and defining the concept of abuse of discretion rests in the last analysis on nothing else but the endeavor to place emphasis on the idea of law in the face of authority, and thus to serve the needs of the citizen by marking out the boundaries of administrative concern. What is involved here is the maintenance of an equilibrium in the vital relationship between government and the individual, and

62. Cf. Jellinek, Gesetz, Gesetzesanwendung und ZweckmässigkeitserwäGUNG (I913) 340 et seq., 348 et seq.

63. Morstein Marx, Die "Offentliche Hand" als privatrechtlich organisierte Staatsverwaltung (I929) I2 HANSEATISCHE RECHTS- UND GERICHTS-ZEITSCHRIFT 587, 594. Cf. FleINER, op. cit. silpra note 55, at I47-148; I MAYER, op. cit. silpra note 58, at 98, I08, 254 . 
therefore one of the fundamental problems of political organization itself." 64

Free resort to private agreements under civil law by administrative agencies would defeat the cardinal objective of administrative law. "The greater elasticity of civil law means for all practical purposes a widened authorization for public administration, an uncontemplated accrual of power, without a corresponding counterpoise in favor of the citizen as an individual. Therein lies a danger not to be underestimated because the consequent expansion of administrative power appears almost boundless. The danger can be met only by a determined throttling of government activities parading in the disguise of civil law. Without such throttling, the system of public law would lose its significance." 65

\section{IV}

Of French administrative law, it can well be said that "it appears founded on the prerogative of the individual". ${ }^{66}$ For decades, the Conseil d'Etat has given the concept of excess of power "a very broad construction" so as to make it "synonymous with abuse of power". ${ }^{67}$ Beyond the Rhine, prior to the advent of the Third Reich, German administrative law reflected in its application the principle that "the presumption is in favor of the citizen's freedom from governmental coercion". 68

Today, National Socialist doctrine is eating holes into the texture of the substantive law. For the Secret Police it has been claimed that "the scope of political considerations, i. e., the factors touching upon the vital interests of the national community and hence belonging to the competence of the Secret Police, cannot be determined rationally, but can be determined only for each single case by the Secret Police itself". ${ }^{69}$ The change of emphasis, however, does not dispose of the comparative significance of the German system of administrative law developed under the auspices of the Second Reich and perfected further during the republican era, particularly since German theory and practice has displayed greater responsiveness to French precedent than was

64. Morstein Marx, op. cit. supra note 63, at 595 .

65. Id. at 595-596. Cf. FleiNer, op. cit. supra note 55, at I26.

66. 2 MESTRE, I IIMITI DEL SINDICATO CONTENZIOSO NEI RIGUARDI DEGLI ATTI DELL'AUTORITÀ AMMINISTRATIVA, STUDI DI DIRITTO PUBblico IN ONORE DI ORESTE RANELIETII (I93I) I33, I42.

67. Serrigny, Traité de L'ORganization de la COMPÉtence et DE LA PRocÉdure EN MATIÉRE CONTENTIEUSE ADMINISTRATIVE (I865) 309. Cf. RIESENFED, op. cit. supra note 4 , at $425-426$.

68. FLEINER, op. cit. supra note 55 , at $13 \mathrm{I}, 389$.

69. Hamel, Die Polizei im Nationalsozialistischen Staat (I935) 40 DeUTsche JURISTEN-ZEITUNG 326, 330. The author derives encouragement from some of the more recent decisions of the Italian Consiglio di Stato without quite grasping the significance of these decisions. 
the case vice versa. ${ }^{70}$ Under the Weimar Constitution, no exaggeration was involved in the statement that both legal authorities and administrative courts were "in unqualified agreement" as to the legal principles relating to administrative discretion: that "even free discretion must always be exercised solely as discretion according to official duties; that it is an illegitimate transgression of the bounds of discretion, consequently an abuse of discretion, therefore illegal action, if the exercise of free discretion is determined by extraneous considerations". ${ }^{71}$

Continental European administrative law has displayed no eagerness to hold the legislator to the requirement of supplying administrative agencies with unequivocal directives for the exercise of discretionary power. This disinclination has arisen from practical considerations. The modern "service state" assigns to legislative bodies exacting tasks of unprecedented magnitude and complexity. Sheer pressure of time makes it impossible for the representative assembly to incorporate into the statute detailed specifications for the methods and techniques by which the administrator attempts to realize the statutory objectives. Nor can it be assumed that the lawmaker is adequately equipped for any such assignments. He is unable to foresee the perplexing questions which may present themselves in the process of enforcement on the administrative plane; he cannot be expected to meet them in terms of statutory clauses. Moreover, it should be conceded that the administrator, being on the scene of enforcement operations, is in a more favorable position to develop an intelligent approach to the discharge of the function with which the statute entrusts him. ${ }^{72}$ To effect rational procedure on the administrative level requires a considerable degree of flexibility of directives. To place the administrator in a straightjacket of superimposed standards carries with it the danger of a defeat of the very purpose of the statute. It is not safe to tie the steering-wheel of the car in order to check extravagant urges of the driver.

In addition, there can be no doubt that it is socially undesirable to offer redress in individual cases of abuse of discretionary power by voiding the authorizing statute because of a lack of explicit criteria

70. Cf. FreUnd, op. cit. supra note 2 , at 4 .

7I. Perels, supra note 53, at 97. Cf. Prussian Supreme Administrative Court, Oct. I, I909 (I909) 55 Entscheidungen des Preussischen Oberverwaltungsgerichts 459; BÜHLER, DIE SUBJERTIVEN ÖFFENTLICHEN RECHTE UND IHR SCHUTZ IN DER DEUTSCHEN VERWALTUNGSRECHTSSPRECHUNG (I9I4) 24 ; JELIINEK, op. cit. supra note 62 , at 347 ; LAUN, DAS FREIE ERMIESSEN UND SEINE GRENZEN (I9xo) 262. For relevant decisions of the Saxon Supreme Administrative Court, see ApELt, DAS SÄchsische Gesetz ÜBER DIE VERWALTUNGSGERICHTSBARKEIT (I9II) 286 . For a corresponding decision of the Baden Supreme Administrative Court, see BüHLER, op. cit. supra at I63.

72. The same thesis is elaborated from a somewhat different vantage point by LANDIs, loc. cit. supra note 3. 
to guide administrative action. ${ }^{73}$ Instead of rectifying the situation by disposing of the specific administrative act, the court, by declaring the statute invalid, exceeds by far the necessities of the case. The result is a legislative vacuum. The outcome is unsatisfactory because it amounts to a needless waste of community energies. Quite apart from the thought of social economy, however, the implied rebuke to the legislator must often appear entirely unwarranted. The interest of the court in obtaining explicit criteria for the review of discretion is disproportionate to the difficulties confronting the legislator in formulating the statute with an eye to fitting it for practical use. It is hardly surprising that the judiciary is prone to overemphasize those considerations which tend to simplify judicial business. An express standard incorporated in the statute offers a handy yardstick for adjudging administrative conduct. But its handiness alone does not compensate for the substantial disadvantages attending its application.

It is clear, on the other hand, that no administrative agency "can be permitted simply to follow its own course oriented toward police state conceptions. The administrative agency is an executor operating in the name and subject to the instructions of the body politic. In the discharge of this function, it is dependent on the confidence of those from whom its mandate is derived: the people'. ${ }^{74}$ While Continental European administrative law has abstained from demanding of the legislative branch legal standardization of administrative conduct in terms of express stipulations, it has reënforced public confidence in the operative establishments of government by developing an extensive judicial scrutiny of administrative action. In this respect, it has contributed to a practical realization of the representative idea by insuring full publicity of government transactions. Costs of administrative litigation are low. Review by administrative courts has not been allowed to dwell on mere hypotheses of legitimate administrative action. By appeal to the courts, the citizen affected by administrative measures was given an opportunity to lift the curtain of official anonymity. The boldness of judicial inquiry was commensurate with

73. A good illustration is petitioner's brief for the Supreme Judicial Court in the Massachusetts case, see supra note 2I. The constitutional argument was presented under the following headings: "A. The statute deprives petitioner of their property without due process of law. B. The statute denies petitioner the equal protection of the law. C. The statute is an unreasonable and unwarranted interference with a lawful private business." The body of the brief is devoted to an analysis of these propositions. Cf. Note (I938) 87 U. of PA. L. REv. 20r. In the Massachusetts case, petitioner placed chief reliance on Yick Wo v. Hopkins, II8 U. S. 356 (I886), and, in the words of the Supreme Judicial Court, "the numerous cases of that class following it." See Liggett Drug Co., Inc. v. Board of License Com'rs of City of North Adams, 4 N. E. (2d) 628,635 (Mass. I936).

74. Morstein Marx, Rechsstaat und Verwaltungsrecht (I929) 87 ZEITSCHRIFT FüR DiE Gesamte StaAtswissenschaft 379, 383. 
the scope of administrative experience on the part of the court membership. ${ }^{75}$

The decisions here presented (II and III) conceive of administrative discretion as essentially embedded in the legal order. Being embedded in the legal order, the discretionary act cannot reach beyond the special purposes which the statute has envisaged in conferring discretionary power. For administrative measures, the claim to compliance rests on their statutory authorization. Benevolence of motive per se counts for naught. ${ }^{76}$ This, in fact, is the distinction between the police state and the representative polity. Since the grant of discretionary power in effect widens the scope of authorization beyond explicit statutory clauses, particular care is required to delimit the borderline between legitimate and illegitimate use of discretionary power. The legality of the discretionary act is dependent on proper motivation. The proper motive is identical with that motive which the statute itself intends to serve. The intention of the statute can be ascertained from its contents and the context of its legislative deliberation, regardless of the absence of express criteria to govern the exercise of discretion. If there be ground for doubt, the doubt would point to the illegality of the administrative act. For no administrative act is valid unless it can be traced back to statutory authorization. Should the extent of the authorization be in doubt, the administrative agency concerned would lack a charter of action.

It follows that we cannot speak of abuse of discretion (depriving the administrative act of legality because of the lack of authorization) only in those cases where the discretionary act is plainly discriminatory. Unless a statute in itself constitutional directs him otherwise, the administrator, acting as the agent of the community, is bound by his official duty to uphold the generality of the law and the equality of citizens by granting no one special favors and imposing on no one special disadvantages. But discrimination is merely the most flagrant abuse of discretionary power. Surely, if he acts in bad faith he acts illegally. It does not follow, however, that his good faith can heal improper motivation. Whether or not his motive is proper is a question of law. It is not a question of the administrator's subjective conception of propriety. His concern may have been with an "entirely

75. As one who has had an opportunity to plead before German administrative courts as the designated representative of his department, I may say that, almost without exception, the judges considered themselves obligated to provide the administrative agency appearing as defendant with a good conception of feasible procedure that would satisfy all legal requirements.

76. The decision as to what objectives are socially desirable, and as such to be pursued by governmental agencies, is a decision reserved for the representative bodies. Administrative agencies are not authorized to anticipate such a decision of the policyformulating organs of government by effecting it incidentally in the law-enforcement process. 
laudable purpose". ${ }^{77}$ Subjectively, he may have considered it his duty to act as he did. Even objectively, he may have aimed at "sound" and "practical" ends. ${ }^{78}$ Still, such motivation is by no means necessarily identical with proper motivation.

Proper motivation is motivation in accordance with discernible intentions of the statute. Extraneous considerations are all those considerations outside the discernible intentions of the statute. The test is not the administrator's good faith. Nor is it general "practicality" or "soundness" of the objectives sought by him to be attained. The test is the nexus between the individual discretionary act and any of those special purposes encompassed in the discernible intentions of the statute. If the nexus does not exist, the discretionary act is illegal because of lack of authorization. An illegal administrative act can not acquire legality by judicial imputation of proper motivation. The proper motive is the key to the question of legality. The question can not be decided without an inquiry into the factual situation from which the contested measure arose. To operate here with assumptions vitiates the idea of law itself. It encourages administrative lawlessness. It is incompatible with the "rule of law".79

Continental European administrative justice has extended its inquiries into the administrative process further than have American courts. In the review of discretion, in particular, it has gone far toward effecting administrative accountability outside the channels of legislative and hierarchical (internal) control-an accountability realized in terms of actio popularis. In performing this function, the administrative courts have not only built up a comprehensive body of precedents but have also provided public administration with a strong legal tradition. ${ }^{80}$ The beneficial results were in no small measure the product of the practical knowledge of the administrative process widely distributed among the court personnel. Speaking generally, the administrative judiciary has recruited much of its membership from the administrative ranks. Under the circumstances, judicial rebuke of

77. In the words of the Hamburg Supreme Administrative Court; see supra p. 970.

78. As the Massachusetts Supreme Judicial Court put it; see silpra p. 960.

79. See supra note 27.

80. In Continental Europe, the teaching approach toward public administration is primarily through the medium of administrative law. Professor William Anderson, one of our leading scholars in the field of public administration, has recently been quoted as "prophesying that in twenty-five years our courses in public administration would be more like the European ones". Social Science Research Council, Committee on Public Administration, Legal Aspects of Public Administration (1939) 7. Administrative law, on the other hand, must preserve, in the words of a German authority, "closest cooperation with its neighbor, public administration". Köttgen, Aufgaben und Methoden der verwaltungsrechtlichen Forschung ( 1938 ) 5, II JAHRBUCH FüR KOMMUNALwISSENSCHAFT 2I8, 225. French administrative law literature abounds in volumes oriented toward the needs of administrative practice. A typical contribution of this kind is

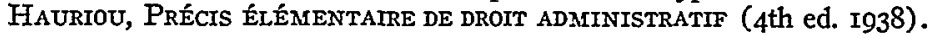


administrative agencies, while gaining special validity because of the composition of the bench, was accepted with grace by the administrator as coming from the mouth of his peers.

The greatest importance of administrative law lies in its formative influence on the very conduct of public administration as a whole. It cannot fail to shape the "administrative mind". It is bound to translate itself into the techniques of public management. ${ }^{81}$ This, I think, is the chief lesson to be drawn from Continental European experience. The presupposition is, of course, an administrative judiciary both set off organizationally from the agencies of public administration and at the same time sufficiently accessible to concern itself with the ordinary run of administrative operations. To be effective, administrative courts must be "average man's courts". In serving as "average man's courts", they must be placed in a position, in terms of the experience of their personnel, to aid the administrator in mapping his course in harmony with the standards of legality.

The Logan Bill concerning the establishment of a United States Court of Appeals for Administration ${ }^{82}$ is a significant move in the direction of overcoming the present inadequacies of judicial review of administrative decisions. It is altogether probable that the thoughts incorporated in this proposal will fail to elicit legislative action in the immediate future. Surely, prolonged contemplation has its merits. The bill, however, deserves commendation for its judicious insistence on a specially qualified bench. ${ }^{83}$ The wording of the bill makes it plain that among the court personnel there must be members who are "expert and experienced in the subject matter", 84 and who possess special qualifications "by way of learning, experience, and special training". ${ }^{85}$ It is gratifying also that the bill envisages the establishment of "divisions" ${ }^{86}$ and "sections" 87 of the court so as to allocate special competence to the individual lines of judicial activity.

The scope of the judicial review function is perhaps defined in terms too narrow. Section II reads: "The review of the court shall be limited to questions of law, and the findings of fact of the commission, administrative authority, or tribunal, if supported by substantial evidence, shall be conclusive." No objections would exist, of course, if the question of law, in controversies arising over the exercise of discretionary power, would be defined as broadly as is suggested in

8I. See supra note 75 .

82. Sen. 3676,75 th Cong., $3 d$ Sess.

83. \$ I (a).

84. \$3 (c).

85. Ibid.

86. § 3 (a) and (b).

87. $\$ 3$ (c). 
the preceding pages. A constructive feature of the bill is to be found in the provision for divisions of the court to "hold special sessions in any part of the United States". ${ }^{88}$ Still, I am inclined to believe that practical necessity would soon point to a supplementation of the court's work by a system of administrative district courts of first resort. ${ }^{80}$ Should this or a similar bill be adopted, however, the greatest benefit would lie in the incentive which thereby would be given to state legislation of the same type. It is in the latter sphere that the individual citizen is least adequately protected against administrative encroachment.

88. § I6.

89. The ambulatory scheme outlined in American Bar Association, Advance Progranr, Report of the Spectal Committee on Administrative Law (ig36) 209, seems to be dictated primarily by the fear of "excessive concentration of power in Washington", to use the phrase of the Committee Recommendations. The decisive practical reason for organizational deconcentration is the increased accessibility of the organs of administrative justice. 